\title{
THISMIA ANGUSTIMITRA (THISMIACEAE), A NEW SPECIES FROM THAILAND
}

\author{
SAHUT CHANTANAORRAPINT \\ PSU-Herbarium, Centre for Biodiversity of Peninsular Thailand (CBiPT), \\ Department of Biology, Faculty of Science, Prince of Songkla University, \\ Hat Yai, Songkhla, 90112, Thailand; e-mail: sahut.c@psu.ac.th
}

SUMMARY

A new species of the genus Thismia (Thismiaceae) from Thailand is described and illustrated.

Key words: Thismiaceae, Thismia angustimitra, Thailand, new species.

\section{INTRODUCTION}

The genus Thismia Griff. had been treated as a part of the family Burmanniaceae (Jonker 1938, 1948, Stone 1980, Jarvie 1996, Saunders 1996, Yang et al. 2002, APG 2003, Tsukaya \& Okada 2005). Interestingly, however, recent molecular phylogenetic research has suggested that Thismia is sister to the Dioscorea clade, not the Burmannia clade, therefore supporting recognition of the Thismiaceae (Merckx et al. 2006). The genus consists of c. 35 species and is concentrated mainly in the Malay Peninsula. All species of the genus are mycotrophic herbs, growing typically amongst leaf litter on shady wet forest floor. In Thailand, two species have been recorded, viz. T. javanica J.J.Sm. and T. mirabilis K.Larsen (Larsen 1965, 1987). During a botanical field trip to Phu Wau Wildlife Sanctuary, Nong Khai Province, north-eastern Thailand in September 2004, a new species was found.

Thismia angustimitra S.Chantanaorrapint, spec. nov. — Fig. 1

Species nova ab affini Thismia mirabilis K.Larsen laminae in mitram angustis et anulo curvatum bene differt. - Typus: Chantanaorrapint 765 (holo PSU!; iso BKF!, L! in glycerine-alcohol), Thailand, Nong Khai Province, Phu Wau Wildlife Sanctuary, c. 200 m alt., $18^{\circ} 09^{\prime} 53^{\prime \prime N}, 103^{\circ} 59^{\prime} 03 " \mathrm{E}, 13$ September 2004.

Plant terrestrial, achlorophyllous, mycotrophic. Root creeping, vermiform, branched, brownish white tip. Stem erect, simple, to $10 \mathrm{~cm}$ tall (including flowers), bearing 1-3 flowers. Leaves scale-like, appressed lanceolate, 3-6 mm long, translucent, apex acute. Involucral bracts 3, white, similar to upper leaves. Flower c. $10 \mathrm{~mm}$ long, perianth of 6 tepals, fused to form an obovate-elliptic chamber, lacking transverse bars inside; outer tepals 3 , white, c. 2 by $4 \mathrm{~mm}$, apex spreading, rounded or mucronate, margin crenate; inner tepals 3, purple to brownish, mitriform with three lateral apertures, aperture 3.5-4.5 mm diam., top of mitre with three fovea; annulus incurved; stamens 6, 


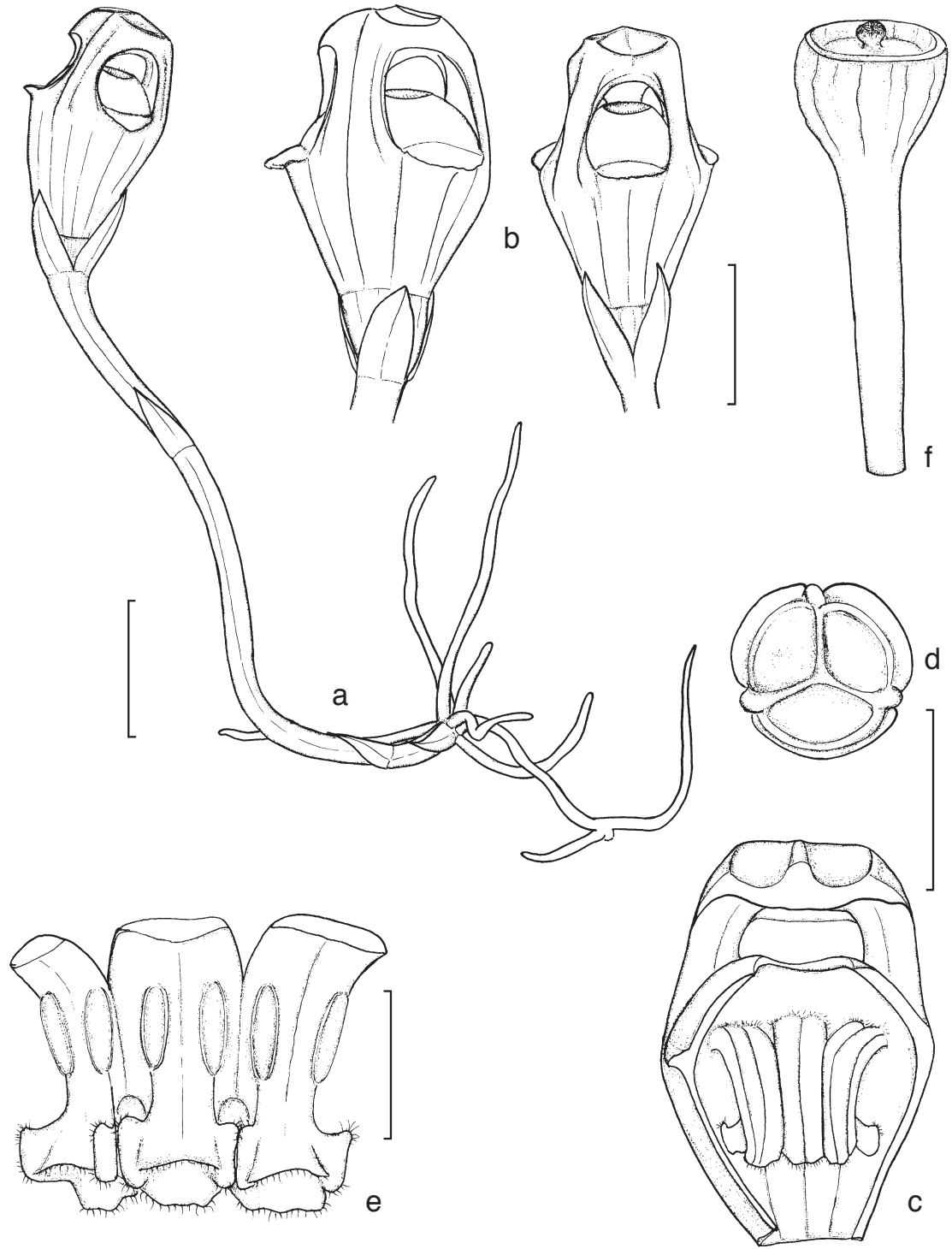

Fig. 1. Thismia angustimitra S.Chantanaorrapint. a. Habit; b. perianth tubes; c. longitudinal section of perianth; d. top view of mitra; e. side view of pendulous stamens; f. fruit (all from Chantanaorrapint 765 , type specimen). - Scale bars: $a-d, f=5 \mathrm{~mm}, \mathrm{e}=2 \mathrm{~mm}$.

connate to form a tube around the style, pendulous from the annulus, hairy, connective broad with a quadrangular wing; anthers oblong, adaxial on the basal part of the stamen; nectariferous gland present towards the apex on the line of fusion between each connective; stigma very short, globose, 3-lobed, papillose. Fruit fleshy, cup-shaped, c. $5 \mathrm{~mm}$ long; fruit stalk thickened and lengthened after flowering to $12 \mathrm{~mm}$ above the bracts. Seed not found. 
Distribution - Known only from the type locality in Phu Wau Wildlife Sanctuary, Nong Khai Province, Thailand.

Ecology \& Phenology - Thismia angustimitra was collected on sandy soil covered by leaf litters at the edge of a mountain in bamboo forest. Elevation $200 \mathrm{~m}$. Flowering and fruiting in the rainy season.

Etymology - The specific name refers to the narrow mitre.

Notes - Thismia angustimitra is closely related to T. mirabilis, a species described from Khao Yai National Park and Ko Chang Island, Thailand, which also has three fovea at the top of the mitre, and has vermiform roots. However, T. angustimitra has a much narrower mitre with curved annulus, whilst $T$. mirabilis has a broad mitre and erect annulus.

Within the treatment of Jonker (1938), T. mirabilis and T. angustimitra appeared to resemble the species in sect. Sarcosiphon, especially T. crocea (Becc.) J.J.Sm., T. clandestina (Blume) Miq. and T. episcopalism (Becc.) J.J.Sm., as they have in common reduced outer perianth lobes and their inner ones are connate to an erect mitre with three holes. However, the former differ from the latter in having vermiform roots, as the species in sect. Sarcosiphon have a coralloid root system.

Concerning the distribution range, as Nong Khai Province has a common border with Laos PDR, it is expected that the new species might occur in Laos PDR as well.

\section{ACKNOWLEDGEMENTS}

The author would like to thank Assoc. Prof. Dr Obchant Thaithong, Department of Botany, Faculty of Science, Chulalongkorn University, Bangkok, Thailand for her financial support of the botanical field trip. Sincere thanks also go to Assoc. Prof. Dr Kitichate Sridith, PSU-Herbarium, Department of Biology, Faculty of Science, Prince of Songkla University, Hat Yai, Songkhla, Thailand for his valuable comments on the first draft of the manuscript.

\section{REFERENCES}

APG (Angiosperm Phylogeny Group). 2003. An update of the Angiosperm Phylogeny Group classification for the orders and families of flowering plants. Bot. J. Linn. Soc. 141: 399-436.

Jarvie, J.E. 1996. Thismia lauriana (Burmanniaceae), a new species from Central Kalimantan. Blumea 41: 257-259.

Jonker, F.P. 1938. A monograph of the Burmanniaceae. Mededeelingen van het Botanisch Museum en Herbarium van de Rijks Universiteit te Utrecht 5: 1-279.

Jonker, F.P. 1948. Burmanniaceae. In: C.G.G.J. van Steenis (ed.), Flora Malesiana, Ser. I, 4: 13-26.

Larsen, K. 1965. Studies in the flora of Thailand 27. Thismiaceae. Dansk Bot. Ark. 23: 171-174.

Larsen, K. 1987. Thismiaceae. In: T. Smitinand \& K. Larsen (eds.), Flora of Thailand 5, 1: 124-126.

Merckx, V., P. Schols, H. Maas-van de Kamer, P. Maas, S. Huysmans \& E. Smets. 2006. Phylogeny and evolution of Burmanniaceae (Dioscoreales) based on nuclear and mitochondrial data. Amer. J. Bot. 93: 1684-1698.

Saunders, R.M.K. 1996. Typification of the name Thismia fumida Ridl. (Burmanniaceae). Taxon 45: 107-109.

Stone, B.C. 1980. Rediscovery of Thismia clavigera (Becc.) F.v.M. (Burmanniaceae). Blumea 26: 419-425.

Tsukaya, H. \& H. Okada. 2005. Thismia mullerensis (Burmanniaceae), a new species from Muller Range, Central Kalimantan. Acta Phytotax. Geobot. 56: 129-133.

Yang, S.-Z., R.M.K. Saunders \& C.-J. Hsu. 2002. Thismia taiwanensis sp. nov. (Burmanniaceae tribe Thismieae): first record of the tribe in China. Syst. Bot. 27: 485-488. 